\title{
Environmental Fate of Heavy Metals in Soil of Ido-Osun Waste Dump Site, Osogbo, Osun, Nigeria
}

\author{
Olayiwola Olajumoke Abidemi ${ }^{1}$, Onwordi Chionyedua Theresa ${ }^{2, *}$ \\ ${ }^{1}$ Chemical Sciences Department, College of Natural and Applied Sciences, P.M.B. 5533, Oduduwa University, Ipetumodu, Ile-Ife, \\ Osun State, Nigeria \\ ${ }^{2}$ Department of Chemistry, Faculty of Science, Lagos State University, P. O. Box 0001, Ojo campu, Lagos, Nigeria \\ *Corresponding author: teresachiedu@yahoo.com
}

Received November 10, 2014; Revised December 20, 2014; Accepted January 03, 2015

\begin{abstract}
Wastes, if not properly managed can cause severe complications within ecosystem. Farmers use soil from dumpsites without regards for the health implication the heavy metal contents of such soil type may pose. The levels of these heavy metals need to be ascertained to know their fate. Five heavy metals (chromium, nickel, zinc, lead and copper) were analysed for their levels in soil at four different directions (east, west, north and south) by wet digestion spectrophotometrically. Heavy metals in soil were zinc $(1133 \pm 897 \mathrm{mg} / \mathrm{kg})$, nickel (26.3 $\pm 51.1 \mathrm{mg} / \mathrm{kg})$, copper $(110 \pm 90 \mathrm{mg} / \mathrm{kg})$, lead $(137 \pm 64 \mathrm{mg} / \mathrm{kg})$ and chromium $(3.63 \pm 2.46 \mathrm{mg} / \mathrm{kg})$. Concentration in sampling site were higher than soils from background with factors of 67 (zinc), 18 (copper), and 20 (lead). Index of geoaccumulation revealed soil to be moderately to strongly polluted with zinc, copper and lead. Inter-element correlation was in the range $0.90-0.99$. Near-by farmlands are exposed to these heavy metals. Surface water near the site will not be usable for irrigation and other categories of water usages. Wastes from the dump site can be reduced, reused and recycled.
\end{abstract}

Keywords: accumulation factor, heavy metals, index of geo-accumulation, soil, waste dumpsite

Cite This Article: Olayiwola Olajumoke Abidemi, and Onwordi Chionyedua Theresa, "Environmental Fate of Heavy Metals in Soil of Ido-Osun Waste Dump Site, Osogbo, Osun, Nigeria.” American Journal of Environmental Protection, vol. 3, no. 1 (2015): 1-4. doi: 10.12691/env-3-1-1.

\section{Introduction}

Environmental pollution as a result of man's increasing activities has increased considerably in the past century due mainly to significant increases in economic activities and industrialization. Several studies have shown that heavy metals such as lead, cadmium, nickel, manganese and chromium amongst others are responsible for certain diseases [1]. Metals found in waste dumpsite exist in various forms either as the pure metal or alloyed with various other metals. Heavy metals impairing the quality of the environment come from various sources that can be categorized into urban-industrial aerosols, liquid and solid wastes from animal and man, mining and industry and agricultural chemicals [2]. The disposals of materials contaminated with heavy metals such as in waste dumpsite are of concern and pose dangers to people in contact with the contaminated soils and plants. Research made it known that toxic metals arising from human activities are accumulated in soil [3]. Both the quality and quantity of solid waste generated in Nigeria vary widely from day to day, season of the year and nature of the waste disposed due to improper waste management $[4,5]$. [5,6] reported that concentrations of heavy metals in soil around waste dump site are influenced by types of wastes, topography, run-off and level of scavenging. The wastes at dumpsite are usually left over a long time to decompose naturally eaten by animals, picked by scavengers or washed away by floods when it rains into the larger creek and rivers thus affecting the surface water quality [7].

Recently, many studies have shown that heavy metals and metalloids with an atomic density $>6 \mathrm{~g} / \mathrm{cm}^{3}$ - from these wastes can accumulate and persist in soils at environmentally hazards levels [8]. Most abandoned waste dumpsites in many towns in Nigeria attract people as fertile ground for cultivating varieties of crops. The cultivated plants take up the metals either as mobile ions present in the soil solution through the root or through foliar adsorption. The uptake of the metals by crops results in the bioaccumulation of these elements in plant tissues. This is known to be influenced by the metal species, plant species and plant part [9]. Indeed, it has been reported that plants grown on soils possessing enhanced metal concentration due to pollution have increased heavy metal ion content [10]. If the consumption of these metals through plant source is not carefully regulated, it may lead to accumulation in man with attendant health hazards. Yet man happens to be the target of numerous other chemical influences in the environment.

The objective of this study is to provide information on the fate of heavy metals in soils at Ido-Osun waste dumpsite in Osogbo, Osun State, Nigeria. This information will guide in formulating an appropriate land use and management policy for this type of ecosystem and 
will also be of benefit to the State Government that is planning to reduce, re-use and re-cycle the wastes generated at this dumpsite in the state to produce bio-fuel.

\section{Material and Method}

\subsection{Study Area}

The study area lies within latitudes $7^{\circ} 46.110^{\prime} \mathrm{N}$ and longitudes $4^{\circ} 32.379^{\prime} \mathrm{E}$ with an elevation of $285 \mathrm{~m}$ above sea level. It serves as the dumpsite where all residents of the state capital, Osogbo dump various types of wastes including hospital wastes, kitchen wastes, poultry wastes, saw-mill wastes, wastes from mechanic workshop, and wastes from various small and large scale industries using various chemicals. Not far from this site are farmlands where various food crops are grown. Some river network can also be seen. Residential houses are not far from this dumpsite with borehole and well as their source of water for various uses. There is a major road beside this dumpsite that connects this town with a neighbouring Iwo Township where vehicular exhaust will even add to the existing waste on the soil.

\subsection{Sampling}

Soil samples were collected by grab sampling at various points in each direction in east, west, north and south of the sampling sites. These were then mixed to form composite samples; the center of the waste dumpsite was taken as zero point. The Dutch Auger was used to collect soil samples at $0-20 \mathrm{~cm}$ depth of the sampling site. Samples were air-dried, ground to fine dust, sieved to pass through a $2 \mathrm{~mm}$ sieve

\subsection{Soil and Instrumental Analysis}

$10 \mathrm{~g}$ of each soil sample was weighed into a $100 \mathrm{~mL}$ conical flask which had already been washed with deionized water followed by the addition of $6 \mathrm{~mL}$ $\mathrm{HNO}_{3} / \mathrm{HClO}_{4}$ acid in ratio 2:1 and left overnight. Each sample was digested at $150^{\circ} \mathrm{C}$ for about 90 minutes and the temperature was increased to $230^{\circ} \mathrm{C}$ for 30 minutes and $\mathrm{HCl}$ solution was added in ratio $1: 1$ to the digested sample and re-digested again for another 30 minutes. The digested sample was washed into $100 \mathrm{~mL}$ volumetric flask. Mixture obtained was cooled down to room temperature to avoid formation of insoluble perchloric compounds and was made up to mark with deionized water. Heavy metals in this digest were determined using atomic absorption spectrophotometer (BUCK 210 VGP) and the amount of each heavy metal was extrapolated from the calibration graph prepared. The amounts of heavy metal obtained were reported as $\mathrm{mg} / \mathrm{kg}$ heavy metal.

Background samples were collected at about $2 \mathrm{~km}$ away from the dumpsite with no dumping activities.

\subsection{Data Analysis}

Accumulation factor (AF) was calculated as ratio of metals in soil sample to the concentration of that metal in the background soil sample. Pearson correlation was carried out with the use of Number Cruncher Statistical System (NCSS) to study inter-element relationship.
To quantify the degree of pollution in the refuse dump soils, the geo-accumulation index, $\mathrm{I}_{\text {geo }}$, was used [11]: Igeo $=\mathrm{In}=\left(\mathrm{Cn} / 1.5^{*} \mathrm{Bn}\right)$. Where $\mathrm{Cn}$ - measured concentration of metal in the refuse dump soil $(\mathrm{mg} / \mathrm{kg})$ : $\mathrm{Bn}$ - Backgrround value of heavy metals (mg/kg); and 1.5 - background value of heavy metal (mg/kg); and 1.5 background matrix correction factor.

\section{Results and Discussion}

\subsection{Chromium Concentration in Soil}

The results of heavy metals measured in soils at the waste dumpsite are presented in Figure 1. The Figure shows chromium in soil at the dumpsite with a mean value of $3.63 \pm 2.46 \mathrm{mg} / \mathrm{kg}$. The highest chromium concentration was obtained in the south direction $(6.00 \pm 7.21 \mathrm{mg} / \mathrm{kg})$. No chromium was determined in the background sample, which implies pollution of the dumpsite environment with chromium. The level was however found to be within the normal range in soils as reported by [12] is as shown in Table 1. The level was found to be lower to what was obtained by [13] in Ghana. Sources of chromium might be due to wastes from household chemicals and cleaners, diesel engines utilizing anti-corrosive agents, rubber, candles and matches etc.

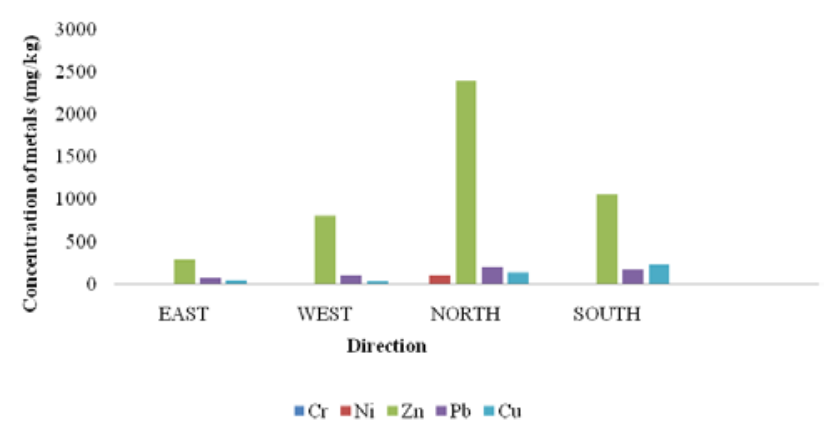

Figure 1. Concentration of heavy metals at different directions of the dumpsite

Table 1. Concentration ranges of metals $(\mathrm{mg} / \mathrm{kg})$ in soils

\begin{tabular}{|c|c|}
\hline \multicolumn{2}{|c|}{ Table 1. Concentration ranges of metals $(\mathbf{m g} / \mathbf{k g})$ in soils } \\
\hline $\mathrm{Cetal}$ & Normal range in soils \\
\hline $\mathrm{Cd}$ & $0.01-2$ \\
\hline $\mathrm{Pb}$ & $0.01-0.5$ \\
\hline $\mathrm{Cr}$ & $2-300$ \\
\hline $\mathrm{Co}$ & $5-1500$ \\
\hline $\mathrm{Ni}$ & $0.5-65$ \\
\hline $\mathrm{Cu}$ & $2-750$ \\
\hline $\mathrm{Zn}$ & $2-250$ \\
\hline $\mathrm{Mo}$ & $1-900$ \\
\hline $\mathrm{As}$ & $0.1-40$ \\
\hline & $0.1-40$ \\
\hline
\end{tabular}

\subsection{Nickel Concentration in Soil}

The level of nickel as shown in Figure 1 was highest in the north direction $(103 \pm 178 \mathrm{mg} / \mathrm{kg})$ with a mean value of $26.3 \pm 51.1 \mathrm{mg} / \mathrm{kg}$. This level was found to be within the normal range of soil reported by [12] but higher compared to the least range of soil of nickel. Level of nickel was however higher than background sample indicating soil environmental nickel pollution in the dumpsite. The level of nickel was found to be higher than what was described by $[13,14,15]$. 


\subsection{Zinc Concentration in Soil}

The amount of zinc present in soil of the study area is as shown in Figure 1. Zinc was found to be higher than other metals with least concentration in east direction $(2388 \pm 2591 \mathrm{mg} / \mathrm{kg})$ with mean concentration of $1133 \pm 897$ $\mathrm{mg} / \mathrm{kg}$. Levels were found to be beyond the range described by [12] with exceptions at east and west directions. Comparison of the level of zinc in the study area with background sample indicates contamination with a factor of 67 as shown in Table 2. Metals are not biodegradable and have toxic effects on living organisms at certain level of concentration. Exposure of man to metals may cause blood and bone disorders, kidney damage and decreased mental capacity and neurological damage $[16,17,18,19]$.

Table 2. Accumulation factor of heavy metals in soil

\begin{tabular}{|c|c|c|c|}
\hline Element & $\begin{array}{c}\text { Study area } \\
(\mathrm{mg} / \mathrm{kg})\end{array}$ & $\begin{array}{c}\text { Background } \\
\text { sample (mg/kg) }\end{array}$ & $\begin{array}{c}\text { Accumulation } \\
\text { factor }\end{array}$ \\
\hline $\mathrm{Cr}$ & 3.63 & $\mathrm{ND}$ & - \\
\hline $\mathrm{Ni}$ & 26.3 & $\mathrm{ND}$ & - \\
\hline $\mathrm{Zn}$ & 1133 & 17 & 67 \\
\hline $\mathrm{Pb}$ & 137 & 7 & 20 \\
\hline $\mathrm{Cu}$ & 110 & 6 & 18 \\
\hline
\end{tabular}

\subsection{Lead Concentration in Soil}

The amount of lead at various directions is as shown in Figure 1. Lowest lead level was obtained in east direction $(65 \pm 58 \mathrm{mg} / \mathrm{kg})$ and highest in south direction $(205 \pm 79$ $\mathrm{mg} / \mathrm{kg}$ ) with lead mean level of $137 \pm 64 \mathrm{mg} / \mathrm{kg}$. The mean level of lead in this study was higher than what was obtained by $[5,13,15,20]$, but compares well with what was reported by [14]. The dumpsite is situated beside a major road in Osogbo leading to Iwo Township. It has been noted that organometallics such as tetraethyl lead $\left(\mathrm{C}_{2} \mathrm{H}_{5}\right)_{4} \mathrm{~Pb}$, an additive to gasoline (petrol) is an important source of $\mathrm{Pb}$ in automobile exhaust emission. The level of lead obtained was found to be within normal range in soils as shown in Table 1, but very higher than the minimum value. Lead level in the study area was found to be higher than background sample with factor of 20 as shown in Table 2. Concentration of lead here might be the contribution from the dumpsite and its location beside a major road. This shows that there is pollution of the soil where lead was disposed and also hazard waste sites where lead has been detected in some environment may be at risk for exposure [20].

\subsection{Copper Concentration of Soil}

Figure 1 illustrates the amount of copper found in soil of the study area. Lowest level of copper was obtained in west direction $(32.0 \pm 21.0 \mathrm{mg} / \mathrm{kg})$ and the highest was obtained in south direction $(228 \pm 174 \mathrm{mg} / \mathrm{kg})$ with mean level of $110 \pm 90 \mathrm{mg} / \mathrm{kg}$. The level of copper in soil was found to be higher than the background sample with accumulation factor of 18 . This indicates pollution of the soil environment with copper. Copper was found to be within normal range in soils as shown in Table 1. Copper soil level in study area was found to be higher than what was reported by $[13,14,20]$ but lower to what was obtained by [21].

The metal loads of soil from the refuse dumpsite were found to be higher than the background values. It was expected because refuse dumps receive considerate waste proportions of product packaging, waste cloths, glass and bottles, newspapers, paints and batteries industrial wastes, dust, ash, tyres, metal cans and containers, medical wastes, abandoned vehicles and insulations which are known to be sources of metals [22,23,24].

Ido-Osun waste dumpsite is presently the only major dumpsite in Osogbo where all wastes in the town are dumped legally and this explains why the level of these metals were higher compared to some other waste dumpsite in literature, except for chromium.

The degree of pollution of the soil of the refuse dump site by heavy metals was assessed as shown in Table 3 using the Geo-accumulation Index (Igeo) classification by [11]: Igeo $>5=$ class 6 (very strong contamination intensity), Igeo $>4-5=$ class 5 (strong to very strong contamination intensity), Igeo $>3-4=$ class 4 (strong intensity), Igeo $>2-3=$ class 3 (moderate to strong contamination intensity), Igeo $>1-2$ = class 2 (moderate contamination intensity), Igeo $>0 \quad-1=$ class 1 (incontaminated to moderate intensity) and Igeo $<0=$ class 0 ( practically uncontaminated).

Table 3. Geo-accumulation Index (Igeo) and classification

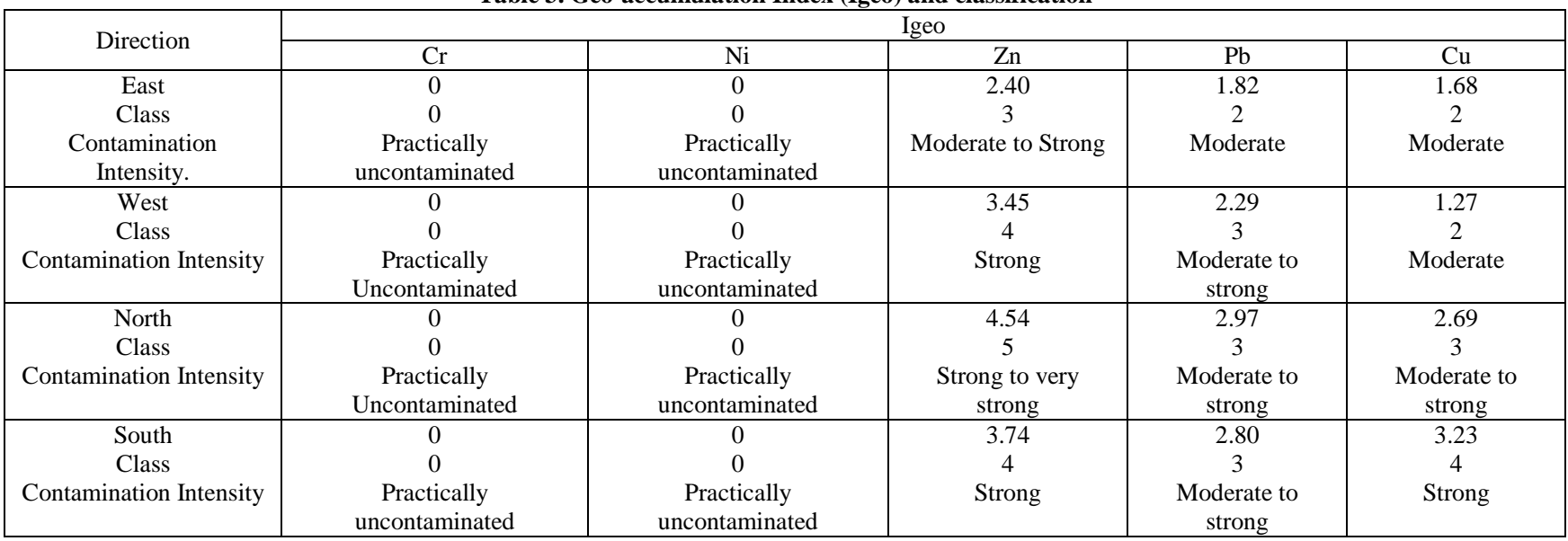

Table 3 explains the contamination intensity of the soil of the study area. The soil was found to be moderately to strongly contaminated with zinc, lead and copper. These results are supported with factor of accumulation obtained,

with zinc (67), lead (20) and copper (18). However, it was found that the soil of the dump site was not contaminated with nickel and chromium with Igeo 0 . The classifications show that the refuse dump site was contaminated with 
zinc, lead and copper which might be due to nature of substances disposed on this land by anthropogenic sources.

Inter-element correlation in soil using the Number Cruncher Statistical Package (NCSS) revealed high correlation between pairs of metals with a positive relationship. $\mathrm{Ni} / \mathrm{Zn}(\mathrm{r}=+0.92), \mathrm{Ni} / \mathrm{Cu}(\mathrm{r}=+0.99), \mathrm{Pb} / \mathrm{Zn}(\mathrm{r}$ $=+0.90), \mathrm{Cu} / \mathrm{Zn}(\mathrm{r}=+0.92), \mathrm{Pb} / \mathrm{Cu}(\mathrm{r}=+0.92)$. This relationship implies the same polluting source of pollution and it was anthropogenic.

\section{Conclusion}

Soil in the dumpsite was found to be higher in the level of heavy metals than the background samples. Data analysis revealed soil to be moderately to strongly polluted with zinc, lead and copper. This implies that the soil from this site can be collected and these metals extracted from them. The investigation revealed that nearby farmland are at risk of pollution of their farm products with accumulation of these metals. Surface water bodies and underground water at residential houses beside the dumpsite should be treated by testing for the amount of metals present in them before they can be used for fishing, irrigation and other categories of water usage. Environmental impact assessment of this site is therefore necessary regularly in order to prevent the general public from being exposed to unnecessary hazards through environmental pollution. The government of the state is about to embark on the utilization of this waste dumpsite for bio-fuel production. It is imperative that plants on this dumpsite be investigated for their heavy metal contents.

\section{Statement of Competing Interests}

The authors have no competing interests.

\section{References}

[1] Hughes, W. W. "Essentials of environmental toxicology. The effects of environmental hazards substances on human health, Tay and Francais, Loma, Lind California " 3 87-95, 1996.

[2] Gerard, K. Environmental engineering. McGraw-Hill,, United Kingdom, 1996

[3] Agirtas, M. S. and Kilicel, F. "Determination of $\mathrm{Cu}, \mathrm{Ni}, \mathrm{Mn}$ and Zn pollution in soil at the shore of Van Lake with flame atomic spectrophotometry," Bulletin of Pure and Applied Science, 18 (c), 45-47, 1999.

[4] Adeniji, K. and Ogu, V. I. "Sustainable physical development in Nigeria," Institute of Social and Economic Research Publication, 1 $1-10,1998$.
[5] Ideriah, T. J. K., Omuaru, V. O. T. and Adiukwu, P. A. "Heavy metal contamination of soils around municipal solid wastes dump in Port Harcourt, Nigeria," Global Journal of Environmental Sciences, 4 (1), 1-4, 2005.

[6] Abidemi, O. O. "Levels of $\mathrm{Pb}, \mathrm{Fe}, \mathrm{Cd}$ and $\mathrm{Co}$ in Soils of Automobile Workshop in Osun State, Nigeria," Journal of Applied Sciences and Environmental Management, 15 (2), 279-282, 2011.

[7] Ogbonna, D. N., Amangabara, G. T. and Ekere, T. O. "Urban solid waste generation in Port Harcourt metropolis and its implications for waste management," Management of Environmrntal Quality, 18 (1), 71-88, 2007.

[8] Alloway, B. J. Heavy metal in soil. John Wiley and Sons Inc York, 1993.

[9] Juste, C. and Mench, M. In: Biogeochemistry of trace metals. (Ed). CRC Press, City, 1992.

[10] Grant, C. and Dobbs, A. J. "The growth and metal content of plants grown in soil contaminated by a copper/chrome/arsenic wood preservative," Environmental Pollution, 14 213-226, 1977.

[11] Forstner, U., Ahlf, W. and Calmano, W. "Sediment quality objectives and criteria development in Germany," Water Science and Technology, 28 (8-9), 307-316, 1993.

[12] Radojevic, M. and Bashkin, V. N. Practical environmental analysis. Cambridge City, 2006.

[13] Agyarko, K., Darteh, E. and Berlinger, B. "Metal levels in some refuse dump soils and plants in Ghana," Plant Soil Environment, 56 (5), 244-251, 2010

[14] Okoronkwo, N. E., Ano, A. O. and Onwuchekwa, E. C. "Environment, health and risk assessment: a case study of the use of an abandoned municipal waste dumpsite for agricultural purpose," African Journal of Biotechnology, 4 (11), 1217-1221, 2005.

[15] Okeyode, I. C. and Rufai, A. A. "Determination of elemental composition of soil samples from some selected dumpsites in Abeokuta, Ogun State, Nigeria using atomic absorption Spectrophotometer," International Journal of Basic and Applied Sciences, 11 55-70, 2011.

[16] National Institute of Environmental Health Services Waste Landfill. City, $2004 . \quad$ Available at http://www.niehs.nih.gov/external/Fag/landfill.htm. 2004.

[17] McCluggage, D. Heavy Metal Poisoning. Published by The Bird Hospital, CO, City, 1991.

[18] Nolan, K. "Copper Toxicity Syndrome," J. Orthomol. Psychiatry, 12 (4), 270-282, 2003.

[19] Ogwuegbu, M. O. C. and Muhanga, W. "Investigation of Lead Concentration in the Blood of People in the Copperbelt Province of Zambia," Journal of Environment, 1 66-75, 2005.

[20] Amusan, A. A., Ige, D. V. and Olawale, R. "Characteristics of soils and crops uptake of metals in municipal waste dump sites in Nigeria," Journal Human Ecology 17 (3), 167-171, 2005.

[21] Purves, D. Solid wastes and the environment-land. Abstracted by C.G. Golueke. Compost Sci, City, 1973.

[22] Zhang, F. S., Yamasaki, S. and Nanzyo, M. "Waste ashes for use in agricultural production. 1. Liming effect, contents of plants nutrients and chemical characteristics of some metals," Science of the Total Environment 284 215-225, 2002.

[23] Pasquini, M. W. and Alexander, M. J. "Chemical properties of urban waste ash produced by open burning on the Jos Plateau; implications for agriculture," The Science of the Total Environment, 319 225-240, 2004.

[24] Woodbury, P. B. Municipal solid waste composts on plants and the environment. City, 2005. 